Article

\title{
Sulphur Dioxide Pads Can Reduce Gray Mold While Maintaining the Quality of Clamshell-Packaged ‘BRS Nubia' Seeded Table Grapes Grown under Protected Cultivation
}

\author{
Khamis Youssef ${ }^{1, *} \mathbb{C}$, Osmar Jose Chaves Junior ${ }^{2}$, Débora Thaís Mühlbeier ${ }^{2} \mathbb{C}$ and \\ Sergio Ruffo Roberto ${ }^{2, *(1)}$ \\ 1 Agricultural Research Center, Plant Pathology Research Institute, 9 Gamaa St., Giza 12619, Egypt \\ 2 Agricultural Research Center, Department of Agronomy, Londrina State University, Londrina 86057-970, PR, \\ Brazil; osmarjcj@gmail.com (O.J.C.J.); muhlbeierdebora@gmail.com (D.T.M.) \\ * Correspondence: youssefeladawy@yahoo.com (K.Y.); sroberto@uel.br (S.R.R.)
}

Received: 3 March 2020; Accepted: 30 March 2020; Published: 1 April 2020

\begin{abstract}
The purpose of this research is to test the efficacy of different types of $\mathrm{SO}_{2}$-generating pads on the incidence of gray mold, and on the physicochemical properties of quality of 'BRS Nubia' seeded table grapes grown under protected cultivation. Four types of $\mathrm{SO}_{2}$-generating pads, $5 \mathrm{or} 8 \mathrm{~g}$ of sodium metabisulfite dual release pads, and 4 or $7 \mathrm{~g}$ of sodium metabisulfite slow release pads, were used. Grapes bunches were harvested from a vineyard covered with plastic mash and stored in a cold room at $1 \pm 1^{\circ} \mathrm{C}$ for 45 days followed by 6 days of shelf life at $22 \pm 1{ }^{\circ} \mathrm{C}$ at a high relative humidity $(>95 \%)$. The results showed that $\mathrm{SO}_{2}$-generating pads with a dual release of 5 or 8 g completely inhibited the development of gray mold at all evaluation times. Also, a high reduction of the disease incidence was achieved by using a slow release of $4 \mathrm{~g}$. The study confirmed that $\mathrm{SO}_{2}$-generating pads did not alter the physicochemical properties of 'BRS Nubia' seeded table grapes including mass loss, berry firmness, color index, total anthocyanin concentration, total soluble solids (TSS), titratable acidity (TA), and the TSS/TA ratio. Slow release pads at 4 and $7 \mathrm{~g}$ reduced the percentage of shattered berries by 56 and $48 \%$ as compared to control only after 6 days of shelf life. Also, all types of $\mathrm{SO}_{2}$-generating pads reduced the stem browning score at the end of cold storage. The 5 or $8 \mathrm{~g}$ dual release pads and $4 \mathrm{~g}$ slow release pads can be considered for effective controlling of gray mold for ‘BRS Nubia' table grapes grown under protected cultivation while maintaining grape quality.
\end{abstract}

Keywords: grapes; fruit quality; $\mathrm{SO}_{2} ;$ Botrytis cinerea; rots

\section{Introduction}

The worldwide harvested area of grapes is estimated to be around 7,157,658 ha with a production of 79,125,982 metric tons. The Brazilian grape industry accounts for about 74,472 ha of harvested area, producing almost 1,591,986 metric tons [1]. 'BRS Nubia' (Vitis sp.) is a new black hybrid seeded table grape grown in the tropical and subtropical areas that requires less labor to cultivate and has a high yield, large berries, and uniform color [2]. This cultivar was obtained by crossing 'Michele Palieri' and Arkansas 2095 grapevines and has the capability of drawing the attention of customers from internal and external markets, since there is a large demand for table grapes for extended periods throughout the year globally [2,3]. 'BRS Nubia' is commonly trained on an overhead trellis system protected by a black screen with $18 \%$ shading.

During cold storage and shelf life periods, table grapes face severe postharvest problems including gray mold $[4,5]$. This disease is caused by Botrytis cinerea and causes huge losses on grapes worldwide, 
even when grapes are packaged in clamshells [6-8]. The control of gray mold is not easy, since postharvest applications with chemical fungicides are not allowed in many countries. As a standard preharvest treatment, fungicides such as iprodione, boscalid, chlorothalonil, captan, mancozeb, procymidone, pyrimethanil, and thiophanate-methyl are commonly used to prevent gray mold of table grapes $[6,9,10]$. As a postharvest treatment, the use of $\mathrm{SO}_{2}$-generating pads during cold storage is commercially implemented to manage gray mold of table grapes [11]. Dual release $\mathrm{SO}_{2}$ generators inside the boxes have been commonly used for grape storage and transportation for periods up to two months $[7,12,13]$. Grape exporters are always worried about limited long-distance transport of fresh grapes, especially when intensive production occurs in subtropical areas where two crops per year is possible. In this case, grapes can be harvested during situations highly favorable for the development of gray mold disease. The main importers of grapes, such as the EU and USA, established tolerance rates for the use of $\mathrm{SO}_{2}$ in postharvest control.

The effectiveness of common packaging methods such as plastic bags or carton boxes on the quality of grapes has been extensively evaluated [14,15]. Nowadays, the use of clamshells has become a consequential approach for packaging of table grapes for domestic and overseas markets in a professional way to offer fresh grapes of better quality to consumers. As 'BRS Nubia' is a new hybrid table grape, there is no available data regarding the behavior of this cultivar packaged in vented clamshells during cold storage and shelf life periods in terms of gray mold incidence and grape quality, especially when vines are grown under protected cultivation. Under this situation, pathogens may find different conditions than in open-field production systems, and different postharvest techniques may be required. In this perspective, the aim of this work was to investigate the effect of different types of $\mathrm{SO}_{2}$-generating pads on the incidence of gray mold and on physicochemical properties of 'BRS Nubia' seeded grapes grown under protected cultivation and packaged in clamshells.

\section{Materials and Methods}

\subsection{Cultivar and Materials Used}

'BRS Nubia' (Vitis sp.) seeded table grapes were harvested from a commercial vineyard located in Marialva, State of Parana, Brazil. The vines were 7 years old and were trained on an overhead trellis system under protected cultivation using a plastic black mesh with $18 \%$ shading. This area was chosen since it has a historical incidence of gray mold disease. At harvest, the total soluble solids (TSS) content of the grapes was $16.2^{\circ}$ Brix. Four types of $\mathrm{SO}_{2}$-generating pads (Uvas Quality Grape Guard, Suragra S.A., San Bernardo, Chile) were used: (i) Slow-release pad having $4 \mathrm{~g}$ of sodium metabisulfite (SM) was prepared with coextruded polymer film; (ii) slow-release pad containing $7 \mathrm{~g}$ of SM was prepared with two polymer films including $\mathrm{SO}_{2}$ in a solvent-free wax matrix; (iii) dual-release pad having $5 \mathrm{~g}$ of $\mathrm{SM}$ was prepared with extruded polymer film and $100 \%$ virgin paper pulp (VPP) obtained by a mechanical procedure, with amount of fast and slow phases of 1 and $4 \mathrm{~g}$ of SM, respectively; and (v) dual-release pad containing $8 \mathrm{~g}$ of SM prepared from coextruded paper with polyethylene and $100 \%$ (VPP), with fast and slow release phases of 1 and $7 \mathrm{~g}$ of SM, respectively. Macroperforated liners (MLs) with $0.3 \%$ of ventilation area (Suragra S.A., San Bernardo, Chile), and vent holes $(70 \times 90 \mathrm{~mm})$, were used for all treatments including the control. Those macroperforated liners were prepared with high-density plastic and master batch $(95 \times 65 \mathrm{~cm})$ and $12 \mu \mathrm{m}$ thickness.

\subsection{Treatments}

Grape bunches free from any disorders or visual symptoms were chosen and arranged according to bunch size and shape. Grapes were accommodated in $20 \times 10 \mathrm{~cm}$ vented clamshells (10 holes distribution) with around $0.5 \mathrm{~kg}$ capacity. Clamshells were wrapped in MLs ( $0.3 \%$ ventilation area). Then ten clamshells were located inside corrugated carton boxes $(100 \times 60 \times 40 \mathrm{~cm}$ each). On the base, a unilaminar sheet of moisture-absorbing paper $\left(33 \times 46 \mathrm{~cm}\right.$ dimension and $50 \mathrm{~g} \mathrm{~m}^{-2}$ density) was located. For each carton box, $\mathrm{aSO}_{2}$-generating pad was placed over the clamshells. Five treatments 
were arranged according to the $\mathrm{SO}_{2}$-generating pad used as follow: (i) Slow release $4 \mathrm{~g} \mathrm{SM}$; (ii) slow release $7 \mathrm{~g} \mathrm{SM}$; (iii) dual release $5 \mathrm{~g} \mathrm{SM}$; (iv) dual release $8 \mathrm{~g} \mathrm{SM}$; and (v) control treatment. All bunches were treated before harvest with iprodione at $0.2 \%$ three times during the season as commonly used by grape growers in the region. A completely randomized design including five treatments and four replicates of each was used. Each replicate consisted of 10 clamshells totaling 40 clamshells per each treatment.

\subsection{Storage and Assessments}

All carton boxes were stored in a cold room at $1 \pm 1{ }^{\circ} \mathrm{C}$ for 45 days followed by 6 days of shelf-life at $22 \pm 1{ }^{\circ} \mathrm{C}$ and high $\mathrm{RH}(>95 \%)$. MLs, absorbent paper sheets, and $\mathrm{SO}_{2}$-generating pads were removed from the boxes at the end of cold storage. Gray mold incidence (\%) was evaluated at 30 days of cold storage (DCS), 45 DCS, 3 days of shelf life (DSL), and 6 DSL according to the following formula: Disease incidence $(\%)=($ number of affected berries/total of berries $) \times 100$ [4]. At the end of cold storage (45 DCS) and at the end of shelf life (6 DSL), mass loss (\%), shattered berries (\%), stem browning, berry firmness (N), TSS, titratable acidity (TA), and TSS/TA ratio and color index (CIRG) were evaluated according to Ahmed et al. (2019) [15] and Chaves Junior et al. (2019) [8]. Also, total anthocyanin concentration was evaluated only at the end of shelf life (6 DSL) following the methods of Shahab et al., (2019) [16].

Mass loss (\%) was calculated by weighing the grape bunches at the initial time of storage and at the examined time [17]: Loss of mass $(\%)=$ (initial mass-mass at examined date/initial mass $) \times$ 100. Shattered berries were evaluated as: Shattered berries $(\%)=$ (number of shattered berries inside the clamshells/total number of berries) $\times 100$. Stem browning was measured throughout by a visual scoring system assessment according to Ngcobo et al. (2012) [18]: (1) fresh and green, (2) some light browning, (3) significant browning, and (4) severe browning. Berry firmness was determined using a texture analyzer TA.XT plus (Stable Micro Systems, Surrey, U.K.) with a cylindrical probe (35mm diameter, P35). Berries placed on the stainless steel platform were compressed in their equatorial diameter at $1 \mathrm{~mm} \mathrm{~s}^{-1}$ (probe speed), and firmness was measured as the force $(\mathrm{N})$ needed to deform the berry by $20 \%$ at its equatorial diameter, according to Lijavetzky et al., (2012) [19].

To evaluate TSS, TA, and TSS/TA ratio, 40 berries were collected from each treatment and analyzed following the methods of Youssef et al., (2019) [5]. The berry color was investigated according to Carreño et al., (1995) [20] using a colorimeter CR-10 Plus (Konica-Minolta ${ }^{\circledR}$, Tokyo, Japan) to get the following variables from the equatorial portion of grape berries $\left(\mathrm{n}=2\right.$ per berry): $L^{*}$ (lightness), $C^{*}$ (chroma), and $h^{o}$ (hue angle). The color index for red grapes (CIRG) was calculated following the formula CIRG $=\left(180-h^{o}\right) /\left(L^{*}+C^{*}\right)$. Forty berries were collected to be analyzed from each treatment.

For total anthocyanin concentration, $3 \mathrm{~g}$ of berry skin were used from each plot, gently separated from the flesh using a sterile blade, and washed with distilled and deionized water. Skins were dried and added to $30 \mathrm{~mL}$ of acidified methanol ( $\mathrm{HCl} \mathrm{1 \%} \mathrm{+} \mathrm{methanol} 99 \%)$ and left in the dark for $48 \mathrm{~h}$. Total anthocyanin content was evaluated at $520 \mathrm{~nm}$ using a spectrophotometer (Genesys ${ }^{\mathrm{TM}} 10 \mathrm{~S}$ UV-VIS ${ }^{\circledR}$, Thermo Scientific, Waltham, MA, USA), and the results were expressed as mg of total anthocyanins of malvidin-3-glucoside per g of berry skin ( $\mathrm{mg} / \mathrm{g})$ [16].

\subsection{Statistical Analysis}

Data were processed statistically for ANOVA (one-way analysis of variance) using Statistica 6.0 software (Stat Soft Inc., Tulsa, Oklahoma, USA). The experiments were repeated twice and the means were compared using Fisher's protected least significant difference (LSD) test at $p \leq 0.05$. Data (\%) were arcsine transformed before analyses to normalize variance. 


\section{Results}

\subsection{Incidence of Gray Mold (\%)}

The natural incidence of gray mold was evaluated at 30 days of cold storage, 45 days of cold storage, followed by 3 and 6 days of shelf life (Table 1). The results showed that the dual release pads at 5 or $8 \mathrm{~g}$ completely inhibited the development of gray mold at all evaluation intervals. Also, the slow release pads at $4 \mathrm{~g}$ completely inhibited the development of gray mold at 30 days of cold storage and 45 days of cold storage and reduced the incidence by 97 and $93 \%$ at 3 and 6 days of shelf life, respectively. The results demonstrated that there was no significant difference between slow release at $7 \mathrm{~g}$ and the control except at 3 days of shelf life. Generally, the incidence of disease increased overtime and reached the maximum of $9.7 \%$ after 6 days of shelf life.

Table 1. Incidence of gray mold of clamshell-packaged 'BRS Nubia' seeded table grapes after 30 and 45 days of storage in cold storage (CS) at $1 \pm 1{ }^{\circ} \mathrm{C}$ followed by 3 and 6 days at shelf-life (SL) at $22 \pm 1{ }^{\circ} \mathrm{C}$ after the period of cold storage, packaged with different $\mathrm{SO}_{2}$-generating pads.

\begin{tabular}{ccccc}
\hline \multirow{2}{*}{ Treatments } & \multicolumn{4}{c}{ Gray Mold Incidence (\%) } \\
\cline { 2 - 5 } & 30 Days of CS & 45 Days of CS & 3 Days of SL & 6 Days of SL \\
\hline Slow release-4 g & $0.00 \pm 0.00 \mathrm{~b}^{\mathrm{z}}$ & $0.00 \pm 0.00 \mathrm{~b}$ & $0.18 \pm 0.18 \mathrm{c}$ & $0.60 \pm 0.39 \mathrm{~b}$ \\
Slow release-7 g & $0.83 \pm 0.31 \mathrm{ab}$ & $1.84 \pm 0.72 \mathrm{a}$ & $3.15 \pm 1.26 \mathrm{~b}$ & $10.95 \pm 1.31 \mathrm{a}$ \\
Dual release-5 g & $0.00 \pm 0.00 \mathrm{~b}$ & $0.00 \pm 0.00 \mathrm{~b}$ & $0.00 \pm 0.00 \mathrm{c}$ & $0.00 \pm 0.00 \mathrm{~b}$ \\
Dual release-8 g & $0.00 \pm 0.00 \mathrm{~b}$ & $0.00 \pm 0.00 \mathrm{~b}$ & $0.00 \pm 0.00 \mathrm{c}$ & $0.00 \pm 0.00 \mathrm{~b}$ \\
Control & $1.81 \pm 1.09 \mathrm{a}$ & $2.99 \pm 0.68 \mathrm{a}$ & $6.72 \pm 1.70 \mathrm{a}$ & $9.71 \pm 2.96 \mathrm{a}$ \\
\hline
\end{tabular}

${ }^{\mathrm{z}}$ Means ( \pm standard error) in columns marked with the same letters are not significantly different by Fisher's protected LSD test at $p \leq 0.05$.

\subsection{Mass Loss (\%)}

The percentage of mass loss was measured at the end of cold storage ( 45 days) and at the end of shelf life (6 days) (Table 2). Results showed no significant difference among treatments as compared to the control after 45 days of cold storage and at 6 days of shelf life. The mass loss ranged from 3.66-5.30 and $7.44-9.56 \%$ at the end of cold storage and end of shelf life, respectively.

Table 2. Mass loss (\%) and shattered berries (\%) of clamshell-packaged 'BRS Nubia' seeded table grapes after 45 days of storage in cold storage (CS) at $1 \pm 1{ }^{\circ} \mathrm{C}$ followed by 6 days at shelf life (SL) at $22 \pm 1{ }^{\circ} \mathrm{C}$, packaged with different $\mathrm{SO}_{2}$-generating pads.

\begin{tabular}{ccccc}
\hline \multirow{2}{*}{ Treatments } & \multicolumn{2}{c}{ Mass Loss (\%) } & \multicolumn{2}{c}{ Shattered Berries (\%) } \\
\cline { 2 - 5 } & 45 Days in CS & 6 Days of SL & 45 Days in CS & 6 Days of SL \\
\hline Slow release-4 g & $3.66 \pm 0.41 \mathrm{a}^{\mathrm{z}}$ & $9.56 \pm 1.52 \mathrm{a}$ & $2.48 \pm 0.91 \mathrm{ab}$ & $5.16 \pm 0.78 \mathrm{~b}$ \\
Slow release-7 g & $3.84 \pm 0.14 \mathrm{a}$ & $9.06 \pm 0.58 \mathrm{a}$ & $1.69 \pm 0.63 \mathrm{~b}$ & $6.12 \pm 0.75 \mathrm{~b}$ \\
Dual release-5 g & $4.01 \pm 0.12 \mathrm{a}$ & $7.70 \pm 1.14 \mathrm{a}$ & $3.51 \pm 0.54 \mathrm{ab}$ & $10.51 \pm 0.84 \mathrm{a}$ \\
Dual release-8 g & $4.23 \pm 1.36 \mathrm{a}$ & $7.69 \pm 1.19 \mathrm{a}$ & $5.80 \pm 1.82 \mathrm{a}$ & $11.41 \pm 1.52 \mathrm{a}$ \\
Control & $5.30 \pm 1.46 \mathrm{a}$ & $7.44 \pm 0.33 \mathrm{a}$ & $4.81 \pm 0.71 \mathrm{ab}$ & $11.87 \pm 1.17 \mathrm{a}$ \\
\hline
\end{tabular}

${ }^{\mathrm{z}}$ Means ( \pm standard error) in columns marked with the same letters are not significantly different by Fisher's protected LSD test at $p \leq 0.05$.

\subsection{Shattered Berries (\%)}

The percentage of shattered berries was evaluated at the end of cold storage (45 days) and at the end of shelf life (6 days) (Table 2). The results showed no significant difference among treatments as compared to the controlat the end of cold storage. After 6 days of shelf life, slow release pads at 4 and $7 \mathrm{~g}$ reduced the percentage of shattered berries by 56 and $48 \%$ as compared to the control. Overall, the 
percentage of shattered berries ranged from $1.69-5.8 \%$ and $5.16-11.87 \%$ at the end of cold storage and end of shelf life, respectively.

\subsection{Stem Browning}

Stem browning, in accordance with the level of darkness, was evaluated at the end of cold storage (45 days) and at the end of shelf life (6 days) (Table 3). At the end of cold storage, all types of $\mathrm{SO}_{2}$-generating pads significantly reduced stem browningas compared with control, and this reduction varied from $15.4-23.0 \%$. At the end of shelf life, there was no significant difference between $\mathrm{SO}_{2}$-generating pads and the control except for dual release at $8 \mathrm{~g}$ which reduced stem browning by $27.8 \%$ as compared to control treatment due its antioxidant effect.

Table 3. Stem browning scores and berry firmness (N) of clamshell-packaged 'BRS Nubia' seeded table grapes after 45 days of storage in cold storage (CS) at $1 \pm 1^{\circ} \mathrm{C}$ followed by 6 days at shelf life (SL) at $22 \pm 1{ }^{\circ} \mathrm{C}$, packaged with different $\mathrm{SO}_{2}$-generating pads.

\begin{tabular}{ccccc}
\hline \multirow{2}{*}{ Treatments } & \multicolumn{2}{c}{ Stem Browning ${ }^{\mathbf{z}}$} & \multicolumn{2}{c}{ Berry Firmness (N) } \\
\cline { 2 - 5 } & 45 Days in CS & 6 Days of SL & 45 Days in CS & 6 Days of SL \\
\hline Slow release-4 g & $2.20 \pm 0.14 \mathrm{~b}^{\mathrm{y}}$ & $2.75 \pm 0.70 \mathrm{ab}$ & $12.01 \pm 0.21 \mathrm{a}$ & $12.27 \pm 0.59 \mathrm{a}$ \\
Slow release-7 g & $2.05 \pm 0.05 \mathrm{~b}$ & $2.55 \pm 0.21 \mathrm{ab}$ & $11.73 \pm 0.85 \mathrm{a}$ & $12.06 \pm 0.34 \mathrm{a}$ \\
Dual release-5 g & $2.00 \pm 0.00 \mathrm{~b}$ & $2.85 \pm 0.13 \mathrm{a}$ & $11.61 \pm 0.56 \mathrm{a}$ & $12.77 \pm 0.69 \mathrm{a}$ \\
Dual release-8 g & $2.00 \pm 0.00 \mathrm{~b}$ & $2.20 \pm 0.16 \mathrm{~b}$ & $11.33 \pm 0.46 \mathrm{a}$ & $11.77 \pm 0.32 \mathrm{a}$ \\
Control & $2.60 \pm 0.14 \mathrm{a}$ & $3.05 \pm 0.27 \mathrm{a}$ & $11.62 \pm 1.01 \mathrm{a}$ & $12.74 \pm 0.35 \mathrm{a}$ \\
\hline
\end{tabular}

z Stem browning scores: (1) fresh and green, (2) some light browning, (3) significant browning, and (4) severe browning. ${ }^{y}$ Means ( \pm standard error) in columns marked with the same letters are not significantly different by Fisher's protected LSD test at $p \leq 0.05$.

\subsection{Berry Firmness (N)}

Berry firmness was evaluated at the end of cold storage ( 45 days) and at the end of shelf life (6 days) (Table 3). In general, no significant differences were noted between treatments with diverse $\mathrm{SO}_{2}$-generating pads and control. Berry firmness ranged from11.3-12.0 and $11.8-12.8 \mathrm{~N}$ at the end of cold storage and end of shelf life, respectively.

\subsection{TSS, TA, and TSS/TA Ratio}

TSS, TA, and TSS/TA ratio was evaluated at the end of cold storage (45 days) and at the end of shelf life ( 6 days) (Table 4). Generally, none of the $\mathrm{SO}_{2}$-generating pads altered berry TSS, TA, and their ratio. TSS ranged from $15.98-16.95$ and $15.65-16.15^{\circ}$ Brix at the end of cold storage and end of shelf life, respectively. TA ranged from $0.86-0.91$ and $0.80-0.86 \%$ at the end of cold storage and end of shelf life, respectively. TSS/TA ratio ranged from17.75-19.23 and 18.31-20.14 at the end of cold storage and end of shelf life, respectively.

Table 4. Total soluble solids-TSS ( ${ }^{\circ}$ Brix), titratable acidity—TA (tartaric acid \%) and their ratio (TSS/TA) of clamshell-packaged 'BRS Nubia' seeded grapes berries at 45 days of cold storage (CS) at $1 \pm 1{ }^{\circ} \mathrm{C}$ followed by 6 days of shelf life (SL) at $22 \pm 1{ }^{\circ} \mathrm{C}$.

\begin{tabular}{ccccccc}
\hline \multirow{2}{*}{ Treatments } & \multicolumn{2}{c}{ TSS $\left({ }^{\circ}\right.$ Brix) } & \multicolumn{2}{c}{ TA (\% of Tartaric Acid) } & \multicolumn{2}{c}{ TSS/TA } \\
\cline { 2 - 7 } & 45 Days CS & 6 Days SL & 45 Days CS & 6 Days SL & 45 Days CS & 6 Days SL \\
\hline Slow release-4 g & $16.30 \pm 0.23 \mathrm{a}$ z & $16.10 \pm 0.08 \mathrm{a}$ & $0.86 \pm 0.00 \mathrm{a}$ & $0.83 \pm 0.02 \mathrm{a}$ & $18.94 \pm 0.27 \mathrm{a}$ & $19.42 \pm 0.51 \mathrm{a}$ \\
Slow release-7 g & $15.98 \pm 0.23 \mathrm{a}$ & $15.93 \pm 0.15 \mathrm{a}$ & $0.89 \pm 0.05 \mathrm{a}$ & $0.82 \pm 0.03 \mathrm{a}$ & $18.06 \pm 0.83 \mathrm{a}$ & $19.51 \pm 0.76 \mathrm{a}$ \\
Dual release-5 g & $16.58 \pm 0.19 \mathrm{a}$ & $15.78 \pm 0.18 \mathrm{a}$ & $0.88 \pm 0.01 \mathrm{a}$ & $0.86 \pm 0.01 \mathrm{a}$ & $18.89 \pm 0.27 \mathrm{a}$ & $18.31 \pm 0.42 \mathrm{a}$ \\
Dual release-8 g & $16.20 \pm 0.35 \mathrm{a}$ & $15.65 \pm 0.10 \mathrm{a}$ & $0.91 \pm 0.02 \mathrm{a}$ & $0.86 \pm 0.01 \mathrm{a}$ & $17.75 \pm 0.70 \mathrm{a}$ & $18.31 \pm 0.23 \mathrm{a}$ \\
Control & $16.95 \pm 0.44 \mathrm{a}$ & $16.15 \pm 0.31 \mathrm{a}$ & $0.88 \pm 0.02 \mathrm{a}$ & $0.80 \pm 0.02 \mathrm{a}$ & $19.23 \pm 0.78 \mathrm{a}$ & $20.14 \pm 0.83 \mathrm{a}$ \\
\hline
\end{tabular}

${ }^{\mathrm{z}}$ Means ( \pm standard error) in columns marked with the same letters are not significantly different by Fisher's protected LSD test at $p \leq 0.05$. 


\subsection{Color Index (CIRG)}

In all cases, for grape berry color index, no significant difference was recorded among different types of $\mathrm{SO}_{2}$-generating pads and the control at the end of cold storage and at the end of shelf life (Table 5). CIRG ranged from1.7-2.2 and 2.1-3.0 at the end of cold storage and end of shelf life, respectively.

Table 5. Color index (CIRG) of clamshell-packaged 'BRS Nubia' seeded table grapes after 45 days of storage in cold storage(CS) at $1 \pm 1^{\circ} \mathrm{C}$ followed by 6 days at shelf life (SL) at $22 \pm 1^{\circ} \mathrm{C}$, packaged with different $\mathrm{SO}_{2}$-generating pads.

\begin{tabular}{ccc}
\hline \multirow{2}{*}{ Treatments } & \multicolumn{2}{c}{ Color Index (CIRG) } \\
\cline { 2 - 3 } & 45 Days of CS & 6 Days of SL \\
\hline Slow release-4 g & $2.04 \pm 0.25 \mathrm{a}^{\mathrm{z}}$ & $2.07 \pm 0.07 \mathrm{~b}$ \\
Slow release-7 g & $2.00 \pm 0.26 \mathrm{a}$ & $2.13 \pm 0.03 \mathrm{~b}$ \\
Dual release-5 g & $2.16 \pm 0.11 \mathrm{a}$ & $3.01 \pm 0.55 \mathrm{a}$ \\
Dual release-8 g & $1.66 \pm 0.37 \mathrm{a}$ & $2.43 \pm 0.04 \mathrm{ab}$ \\
Control & $2.04 \pm 0.04 \mathrm{a}$ & $2.35 \pm 0.07 \mathrm{ab}$ \\
\hline
\end{tabular}

${ }^{\mathrm{z}}$ Means ( \pm standard error) in columns marked with the same letters are not significantly different by Fisher's protected LSD test at $p \leq 0.05$.

\subsection{Anthocyanins Concentration}

At the end of shelf life, the total anthocyanin concentration of the skin was not affected by the use of different types of $\mathrm{SO}_{2}$-generating pads. This concentration was $4.64,4.14,4.81,4.95$, and $4.50 \mathrm{mg} / \mathrm{g}$ for slow release pad at $4 \mathrm{~g}$, slow release pad at $7 \mathrm{~g}$, dual release pad at $5 \mathrm{~g}$, dual release pad at $8 \mathrm{~g}$, and the control, respectively.

\section{Discussion}

Generally, grapes are susceptible to severe losses because of some diseases, such as gray mold caused by $B$. cinerea. $\mathrm{SO}_{2}$-generating pads areconsidered one of the most important control methods of this disease, particularly when table grapes are cold stored for extended periods $[9,15]$. Nowadays, the trend of 'BRS Nubia' seeded grape growers is to prolong postharvest life for both domestic and international markets.

The results obtained herein showed that $\mathrm{SO}_{2}$-generating pads with dual release at 5 or $8 \mathrm{~g}$ completely inhibited the development of gray mold at all evaluation times. Also, a high reduction of the disease was achieved by using the slow release at $4 \mathrm{~g}$. Those treatments were able to protect the grapes until 45 days of cold storage followed by 6 days of shelf life. The results revealed that 'BRS Nubia' seeded grapes packaged in clamshells were not affected by the $\mathrm{SO}_{2}$ emitted in slow release pads $7 \mathrm{~g}$ except at 3 days of shelf life. The gas release associated with dual release at 5 or $8 \mathrm{~g}$ or slow release at $4 \mathrm{~g}$ may have worked against the initial disease progress and killed the pathogen more efficiently when those treatments were applied. Those results are in agreement with previous studies against gray mold of stored 'Calmeria', 'Red Globe', and 'BRS Vitoria' table grapes [7,21-23]. This performance of different slow release $\mathrm{SO}_{2}$-generating pads can be variedby diverse types of polymer films, coating materials, and release forms $[8,24]$ which provide diverse permeability and thus control altitude.

Evaluating the effectiveness of a control method is very important under naturally occurring infections, and in this research the real situation was simulated for the recent grape packing which already exists in domestic and overseas markets using clamshells. It is important to mention that the grape cultivar response to different types of $\mathrm{SO}_{2}$-generating pads also has a significant role in terms of the control level of the disease. In a previous study, $\mathrm{SO}_{2}$-releasing pads $(7 \mathrm{~g})$ were able to control gray mold of 'Benitaka' table grapes kept under the same commercial situation with high and low inoculum pressure of the pathogen [8]. The results with dual release pads at 5 and $8 \mathrm{~g}$ against the disease was expected because of the contact with air moisture, which leads to the release of a high quantity of gas 
and therefore removal of any pathogen spores around the berries. Thus, the highest concentration of gas could maintain the clamshell-packaged 'BRS Nubia' seeded table grapes completely free of mold growth during cold storage and shelf life periods. The present results are in agreement with other investigations reported previously with different grape cultivars [9,11,24-26]. Actually, low decay incidence was recorded at 30 and 45 days of cold storage even for the control treatment. In the location where the experiments were carried out, chemical fungicides such as iprodione at $0.2 \%$ is the major means to manage gray mold before harvest by applying the compound three times during the season. Moreover, when good agricultural practices are applied, low natural incidence is expected [27-29].

Because it is consumed fresh, the appearance and quality of the table grapes are crucial factors for its marketability. The current study confirmed that $\mathrm{SO}_{2}$-generating pads did not alter the physicochemical properties of 'BRS Nubia' seeded table grapes such as mass loss, berry firmness, color index, anthocyanin content, TSS, TA, and TSS/TA ratio. Also, minor changes were noted for shattered berries and stem browning. In particular, slow release pads at 4 and $7 \mathrm{~g}$ reduced the percentage of shattered berries by 56 and $48 \%$ as compared to the control only after 6 days of shelf life. In addition, all types of $\mathrm{SO}_{2}$-generating pads reduced the stem browning score at the end of cold storage. After 30 days of cold storage there was no statistical difference among the treatments in stem browning (data not shown). Additionally, the phase from grape harvest to marketing is very important in terms of the maintenance of fruit quality [15]. Our results revealed that 'BRS Nubia' grapes have a great prospect for internal and overseas markets, as high fruit quality can be obtained after 45 days of cold storage and also after 6 days of shelf life. Also, it is important to mention that a high initial quality of the grapes is essential.

The efficacy of a treatment on fruit quality is frequently disregarded, especially in laboratory experiments or small scale trials since those kinds of experiments are focused mainly on the treatment to control the disease, ignoring the quality of the final products [30-34]. In addition, table grapes grown under protection cultivation may require specific postharvest treatments, since some fungi may find a different condition to develop and cause losses [35]. However, the use of plastic mesh to cover the vineyard did not negatively affect the postharvest conditions of 'BRS Nubia' table grapes, and the use of clamshells did not interfere with $\mathrm{SO}_{2}$ circulation inside the boxes. Recently, a strong correlation was shown between anthocyanin concentration and color index of 'Benitaka' grape berries [36].

In conclusion, 'BRS Nubia' seeded table grape is a promising cultivar for domestic and international markets. Maintaining quality during cold storage and shelf life periods is an essential requirementfor the producers with respect to cultivar competition. As a postharvest treatment, dual release $\mathrm{SO}_{2}$-generating pads at 5 or $8 \mathrm{~g}$ and slow release pads at $4 \mathrm{~g}$ can be considered as effective control of gray mold for 'BRS Nubia' table grapes while maintaining bunch quality, particularly for overseas export markets or long distance shipment.

Author Contributions: S.R.R. conceived the research idea. O.J.C.J., K.Y. and D.T.M. helped to collect the data. K.Y. and O.J.C.J. also analyzed the data and wrote the paper. All authors have read and agreed to the published version of the manuscript.

Funding: This research received no external funding.

Acknowledgments: The authors are grateful for the financial support provided by Brazilian Council for Scientific and Technological Development (CNPq) grant \#315844/2018-3 to Youssef Khamis. The authors thank Suragra S.A. (Chile) for providing packing materials.

Conflicts of Interest: The authors declare no conflict of interest.

\section{References}

1. FAOSTAT. Available online: http://www.fao.org/faostat/en/\#data/QC (accessed on 17 March 2020).

2. Ritschel, P.S.; Girardi, C.L.; Zanus, M.C.; Fajardo, T.V.M.; Maia, J.D.G.; Souza, R.T.; Naves, R.L.; Camargo, U.A. Novel Brazilian grape cultivars. Acta Hortic. 2015, 1082, 157-163. [CrossRef]

3. Silvestre, J.P.; Roberto, S.R.; Colombo, R.C.; Gonçalves, L.S.A.; Koyama, R.; Shahab, M.; Ahmed, S.; de Souza, R.T. Bunch sizing of 'BRS Nubia' table grape by inflorescence management, shoot tipping and berry thinning. Sci. Hortic. 2017, 225, 764-770. [CrossRef] 
4. Hashim, A.F.; Youssef, K.; Abd-Elsalam, K.A. Ecofriendly nanomaterials for controlling gray mold of table grapes and maintaining postharvest quality. Eur. J. Plant Pathol. 2019, 154, 377-388. [CrossRef]

5. Youssef, K.; de Oliveira, A.G.; Tischer, C.A.; Hussain, I.; Roberto, S.R. Synergistic effect of a novel chitosan/silica nanocomposites-based formulation against gray mold of table grapes and its possible mode of action. Int. J. Biol. Macromol. 2019, 141, 247-258. [CrossRef]

6. Kishino, A.A.; Roberto, S.R.; Genta, W. Implantação do pomar. In Viticultura Tropical: O Sistema de Produção de Uvas de Mesas do Paraná, 2nd ed.; Kishino, A.Y., Carvalho, S.L.C., Roberto, S.R., Eds.; Instituto Agronômico do Paraná: Londrina, Brazil, 2019; pp. 161-200.

7. Domingues, A.R.; Roberto, S.R.; Ahmed, S.; Shahab, M.; Chaves Junior, O.J.; Sumida, C.H.; Souza, R.T. Postharvest techniques to prevent the incidence of botrytis mold of 'BRS Vitoria' seedless grape under cold storage. Horticulturae 2018, 4, 17. [CrossRef]

8. Chaves, O.J., Jr.; Youssef, K.; Koyama, R.; Ahmed, S.; Dominguez, A.R.; Mühlbeier, D.T.; Roberto, S.R. Control of gray mold on clamshell-packaged 'Benitaka' table grapes using sulphur dioxide pads and perforated liners. Pathogens 2019, 8, 271.

9. Stammler, G.; Brix, H.D.; Nave, B.; Gold, R.; Schoefl, U. Studies on the biological performance of boscalid and its mode of action. In Modern Fungicides and Antifungal Compounds V, Friedrichroda; Dehne, H.W., Deising, H.B., Gisi, U., Kuck, K.H., Russell, P.E., Lyr, H., Eds.; Deutsche PhytomedizinischeGesellschaft: Braunschweig, Germany, 2008; pp. 45-51.

10. Romanazzi, G.; Feliziani, E. Botrytis cinerea (Gray Mold). In Post-Harvest Decay; Academic Press: New York, NY, USA, 2014; pp. 131-146.

11. Zutahy, Y.; Lichter, A.; Kaplunov, T.; Lurie, S. Extended storage of 'Red Globe'grapes in modified $\mathrm{SO}_{2}$ generating pads. Postharvest Biol. Technol. 2008, 50, 12-17. [CrossRef]

12. Nelson, K.E.; Ahmedullah, M. Packaging decay-control systems for storage and transit of table grapes for export. Am. J. Enol. Vitic. 1976, 27, 74-79.

13. Ahmed, S.; Roberto, S.R.; Domingues, A.R.; Shahab, M.; Chaves Junior, O.J.; Sumida, C.H.; Souza, R.T. Effects of different sulfur dioxide pads on botrytis mold in 'Italia' table grapes under cold storage. Horticulturae 2018, 4, 29. [CrossRef]

14. Lichter, A.; Zutahy, Y.; Kaplunov, T.; Lurie, S. Evaluation of table grape storage in boxes with sulfur dioxide releasing pads with either an internal plastic liner or external wrap. HortTechnol. 2018, 18, 206-214. [CrossRef]

15. Ahmed, S.; Roberto, S.R.; Youssef, K.; Colombo, R.C.; Shahab, M.; Chaves Junior, O.J.; Sumida, C.H.; Souza, R.T. Postharvest preservation of the new hybrid seedless grape, 'BRS Isis', grown under the double-cropping a year system in a subtropical area. Agronomy 2019, 9, 603. [CrossRef]

16. Shahab, M.; Roberto, S.R.; Ahmed, S.; Colombo, R.C.; Silvestre, J.P.; Koyama, R.; de Souza, R.T. Anthocyanin accumulation and color development of 'Benitaka' table grape subjected to exogenous abscisic acid application at different timings of ripening. Agronomy 2019, 9, 164. [CrossRef]

17. Youssef, K.; Roberto, S.R. Applications of salt solutions before and after harvest affect the quality and incidence of postharvest gray mold of 'Italia' table grapes. Postharvest Biol. Technol. 2014, 87, 95-102. [CrossRef]

18. Ngcobo, M.E.K.; Opara, U.L.; Thiart, G.D. Effects of packaging liners on cooling rate and quality attributes of table grape (cv. Regal seedless). Pack. Tech. Sci. 2012, 25, 73-84. [CrossRef]

19. Lijavetzky, D.; Carbonell-Bejerano, P.; Grimplet, J.; Bravo, G.; Flores, P.; Fenoll, J.; Hellín, P.; Oliveros, J.C.; Martínez-Zapater, J.M. Berry flesh and skin ripening features in Vitis vinifera as assessed by transcriptional profiling. PLoS ONE 2012, 7, e39547. [CrossRef]

20. Carreño, J.; Martinez, A. Proposal of an index for the objective evaluation of the color of red table grapes. Food Res. Int. 1995, 28, 373-377. [CrossRef]

21. Mustonen, H.M. The efficacy of a range of sulfur dioxide generating pads against Botrytis cinerea infection and on out-turn quality of Calmeria table grapes. Aust. J. Exper. Agric. 1992, 32, 389-393. [CrossRef]

22. Palou, L.; Crisosto, C.H.; Garner, D.; Basinal, L.M.; Smilanick, J.L.; Zoffoli, J.P. Minimum constant sulfur dioxide emission rates to control gray mold of cold stored table grapes. Am. J. Enol. Vitic. 2002, 52, 110-115.

23. Henríquez, J.L.; Pinochet, S. Impact of ventilation area of the liner bag, in the performance of $\mathrm{SO}_{2}$ generator pads in boxed table grapes. Acta Hortic. 2016, 1144, 267-272. [CrossRef] 
24. Fernandez-Trujillo, J.P.; Obando-Ulloa, J.M.; Baró, R.; Martinez, J.A. Quality of two table grape cultivars treated with single or dual-phase release $\mathrm{SO}_{2}$ generators. J. App. Bot. Food Qual. 2008, 82, 1-8.

25. Zoffoli, J.P.; Latorre, B.A.; Naranjo, P. Hairline, a postharvest cracking disorder in table grapes induced by sulfur dioxide. Postharvest Biol. Technol. 2008, 47, 90-97. [CrossRef]

26. Sortino, G.; Allegra, A.; Passufiume, R.; Gianguzzi, G.; Gullo, G.; Gallota, A. Postharvest application of sulphur dioxide fumigation to improve quality and storage ability of ‘Red Globe' grape cultivar during long cold storage. Chem. Eng. Trans. 2017, 58, 403-408.

27. Youssef, K.; Sanzani, S.M.; Myrta, A.; Ippolito, A. Effect of a novel potassium bicarbonate-based formulation against Penicillium decay of oranges. J. Plant Pathol. 2014, 96, 419-424.

28. Youssef, K.; Abo Rehab, M.A.; El-Ghany, K.M.A. Preliminary investigation of Verticillium wilt on mango trees (Mangifera indica L.) in Egypt. Am. Eurasian J. Sust Agric. 2014, 8, 50-58.

29. Garganese, F.; Sanzani, S.M.; Di Rella, D.; Schena, L.; Ippolito, A. Pre-and postharvest application of alternative means to control Alternaria Brown spot of citrus. Crop Prot. 2019, 121, 73-79. [CrossRef]

30. Lachhab, N.; Sanzani, S.M.; Fallanaj, F.; Youssef, K.; Nigro, F.; Boselli, M.; Ippolito, A. Protein hydrolysates as resistance inducers for controlling green mold of citrus fruit. Acta Hortic. 2015, 1065, 1593-1598. [CrossRef]

31. Youssef, K.; Hashim, A.F.; Margarita, R.; Alghuthaymi, M.A.; Abd-Elsalam, K.A. Fungicidal efficacy of chemically-produced copper nanoparticles against Penicillium digitatum and Fusarium solani on citrus fruit. Philipp. Agric. Sci. 2017, 100, 69-78.

32. Hussien, A.; Ahmed, Y.; Al-Essawy, A.; Youssef, K. Evaluation of different salt-amended electrolysed water to control postharvest molds of citrus. Trop. Plant Pathol. 2018, 43, 10-20. [CrossRef]

33. Roberto, S.R.; Youssef, K.; Hashim, A.F.; Ippolito, A. Nanomaterials as alternative control means against postharvest diseases in fruit crops. Nanomaterials 2019, 9, 1752. [CrossRef]

34. Youssef, K.; Hussien, A. Electrolysed water and salt solutions can reduce green and blue molds while maintain the quality properties of 'Valencia' late oranges. Postharvest Biol. Technol. 2020, 159, 111025. [CrossRef]

35. Genta, W.; Tessmann, D.J.; Roberto, S.R.; Vida, J.B.; Colombo, L.A.; Scapin, C.R.; Ricce, W.S.; Clovis, L.R. Downy mildew management in protected cultivation of table grapes 'BRS Clara'. Pesq. Agrop. Bras. 2010, 45, 1388-1395. [CrossRef]

36. Shahab, M.; Roberto, S.R.; Ahmed, S.; Colombo, R.C.; Silvestre, J.P.; Renata, K.; de Souza, R.T. Relationship between anthocyanins and skin color of table grapes treated with abscisic acid at different stages of berry ripening. Sci. Hort. 2020, 259, 108859. [CrossRef] 